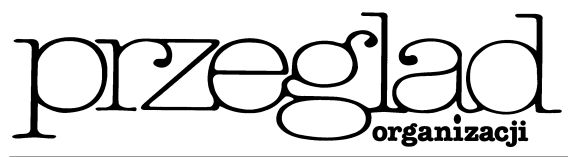

\title{
Rozważania nad tożsamością organizacyjną - konsensus pomiędzy teorią a praktyką
}

https://doi.org/10.33141/po.2005.04.03

Przegląd Organizacji, Nr 4 (783), 2005, ss. 17-19 www.przegladorganizacji.pl

\section{Wprowadzenie}

W dobie globalizacji i coraz bardziej nasilającej się konkurencji przedsiębiorstwa poszukują narzędzi i sposobów, dzięki którym mogą skutecznie wyróżniać się na rynkach, być rozpoznawalne i jednoznacznie kojarzone. Dlatego też obecnie rośnie znaczenie tożsamości organizacyjnej, jej kreowania i zarządzania nią w sposób gwarantujący sukces rynkowy. Niniejsze opracowanie jest próbą uporządkowania poglądów na temat tożsamości organizacyjnej i znalezienia wspólnej płaszczyzny pomiędzy podejściem teoretycznym a praktycznym do tego zagadnienia, tak różnych od siebie, a przecież dotyczących tego samego obszaru organizacji.

\section{Istota tożsamości organizacyjnej}

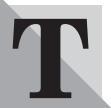

ożsamość organizacyjna (corporate identity) jest bardzo różnie definiowana. Najprościej można określić ją jako zespół cech, które w istotny sposób odróżniają firmę od innych, a zwłaszcza bliskich konkurentów. Tożsamość wpływa na wytworzenie w otoczeniu przedsiębiorstwa określonego wizerunku (corporate image), pozycjonującego firmę. Zatem w tym kontekście można stwierdzić, że kreowanie tożsamości i wizerunku to jedna z podstawowych strategii, mających na celu znalezienie i utrwalenie własnej pozycji wśród innych uczestników ryn$\mathrm{ku}^{1}$. Ten pogląd uzupełnia inna definicja, która określa tożsamość organizacyjną jako zgodność pomiędzy tym, czym organizacja chce być, a tym, jak te działania postrzega otoczenie ${ }^{2)}$.

Można więc powiedzieć, że tożsamość organizacyjna determinuje pewien sposób postępowania i świadomego zarządzania firmą, tworzenia informacji na temat tego, czym jest firma, jak się zmienia, dokąd zmierza i co ją wyróżnia od innych przedsiębiorstw działających na tym samym rynku. Odnosi się także do tego, jak uczestnicy organizacji ją postrzegaja, co czują i co o niej myślą.

Mimo podobnego określenia samego pojęcia tożsamości nie ma jednak zgodności w wielu zasadniczych kwestiach dotyczących corporate identity. Po pierwsze, mimo konsensusu, odnośnie do tożsamości jako jednak pluralistycznego zjawiska, a nie monolitycznego fenomenu ${ }^{3}$, nie ma zgodności, jakie dokładnie elementy wchodzą w skład CIM (corporate identity $m i x)$. Po drugie, istnieje dość spora rozbieżność po- między praktycznym a teoretycznym spojrzeniem na tożsamość organizacyjną. Praktycy skupiają się bardziej na podejściu zorientowanym procesowo, podczas gdy naukowcy są bardziej zainteresowani samą strukturą i składowymi tożsamości.

\section{Teoretyczne ujęcie tożsamości organizacyjnej}

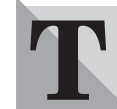
ak jak wcześniej wspomniano, badacze-teoretycy tożsamości organizacyjnej koncentrują się głównie na jej składowych. Najbardziej znana szkoła to szkoła amerykańska i angielska bazujące na postrzeganiu corporate identity przez pryzmat tzw. AC ${ }^{2}$ ID Test ${ }^{\mathrm{TM} 4}$ ). Podejście to postrzega tożsamość organizacyjną jako mieszankę pięciu typów tożsamości: tożsamości rzeczywistej (actual identity), tożsamości przekazywanej (communicated identity), tożsamości postrzeganej (conceived identity), tożsamości doskonałej (ideal identity) oraz tożsamości pożądanej (desired identity) $)^{5}$.

Tożsamość rzeczywista stanowi powszechnie znane atrybuty organizacji i obejmuje m.in. formę własności, styl zarządzania kierownictwa, strukturę organizacyjną, rodzaj działalności i opanowane rynki, a także jakość oferowanych produktów i usług, a więc w rezultacie opisuje ogólną działalność biznesową. Obejmuje także zbiór wartości podzielanych przez zarząd i pracowników. Z kolei tożsamość przekazywana jest najlepiej ujawniona poprzez formalną komunikację wewnatrzorganizacyjną. Przejawia się w reklamach, sponsoringu i działaniach public relations. Jednak w rzeczywistości wywodzi się ona z komunikacji nieformalnej (plotki, komentarze w mediach itp.). Tożsamość postrzegana natomiast odnosi się do odczuwanych przejawów tożsamości, tj. do wizerunku przedsiębiorstwa (corporate design), reputacji firmy oraz tożsamości marki (corporate branding). To właśnie przez te czynniki przedsiębiorstwo jest postrzegane na zewnątrz, a rolą kierownictwa jest branie pod uwagę percepcji najważniejszych grup odbiorców produktów i usług przedsiębiorstwa. Czwarta z kolei tożsamość doskonała dotyczy najkorzystniejszego spozycjonowania przedsiębiorstwa na swoim rynku (rynkach) w określonym przedziale czasu. $Z$ reguły bazuje ona na planowaniu strategicznym, możliwościach organizacyjnych i perspektywach w odniesieniu do kontekstu prowadzenia biznesu, w tym także do środowiska konkurencyjnego. A tożsamość pożądana jest obecna w umysłach przywódców organizacyjnych i jest 
zbieżna z ich wizją organizacji. Często tożsamość ta jest mylona $\mathrm{z}$ tożsamością doskonałą; mają one jednak inne źródła pochodzenia. O ile tożsamość doskonała kształtuje się z reguły po pewnym okresie w wyniku badań i analiz, to tożsamość pożądana jest zbieżna $\mathrm{z}$ wizją przywódcy i jego ego, a nie z racjonalną oceną czy planem działania poprzedzonym serią analiz.

Nieco inne podejście do tożsamości organizacyjnej i jej składowych przedstawia inne amerykańskie źródło, które różnicuje ją tylko na cztery obszary: komunikację i tożsamość wizualną przedsiębiorstwa (communication and visual identity), zachowania (behaviour), kulturę organizacyjną (corporate culture) oraz warunki rynkowe (market conditions) ${ }^{6}$. Według tej koncepcji do komunikacji i tożsamości wizualnej zalicza się system komunikowania się z otoczeniem (corporate communication), komunikację nieformalną (uncontrollable communication), architekturę i lokalizację (architecture and location) oraz tożsamość wizualną (corporate visual identity). Do zachowań można z kolei zaliczyć system zachowania organizacji (corporate behaviour), zachowania kadry kierowniczej ( $m a-$ nagement behaviour), rozumiane jako style kierowania oraz zachowania samych pracowników (employee behaviour). Na kulturę organizacyjną składają się odpowiednio: cele, filozofia i zasady (goals, philosophies and principles), narodowość (nationality) oraz symbolika i historia firmy (organizational imagery and history). Natomiast warunki rynkowe kształtowane są przez charakter przemysłu (nature of industry) oraz strategie korporacyjne i marketingowe (corporate) marketing strategies).

Wydaje się, że można znaleźć wspólny punkt odniesienia pomiędzy tymi dwoma różnymi spojrzeniami na corporate identity. Zestawiając cztery komponenty tożsamości firmy z pięcioma typami tożsamości zawartymi w teście AC ${ }^{2}$ ID Test ${ }^{\mathrm{TM}}$ można dopatrzyć się pewnego podobieństwa i wyróżnić następujące komponenty tożsamości: zachowania, system wizualizacji oraz komunikację z otoczeniem. Zachowania dotyczą działań firmy, które powinny być zgodne z kulturą organizacyjną, misją, celami i strategią. Do zachowań można zaliczyć tożsamość doskonałą, rzeczywistą oraz pożądaną. System wizualizacji odnosi się z kolei do identyfikacji pracowników z firmą. Wiąże się to bezpośrednio z tożsamością postrzeganą. Natomiast komunikacja z otoczeniem dotyczy promowania przedsiębiorstwa i wchodzi w skład tożsamości przekazywanej.

Pokrywa się to z elementami należącymi do CIM, czyli z umysłem organizacji (organizational mind), duszą organizacji (organizational soul) oraz głosem organizacji (organizational voice). Można to dopasować odpowiednio do elementów wyróżnionych wcześniej, tzn.: systemu zachowań, systemu wizualizacji i komunikacji ${ }^{7}$.

\section{Praktyczne ujęcie tożsamości organizacyjnej}

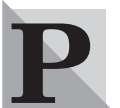

raktyczne spojrzenie na tożsamość organizacyjną skupia się bardziej na podejściu zorientowanym procesowo. Liczą się w nim nie tyle poszczególne składowe, co proces kreowania tożsamości i zarządzania nią w rzeczywistości rynkowej.
Ponadto praktyczne podejście do tożsamości koncentruje się na jej wyraźnych aspektach, a w szczególności tych, które są łatwe w zarządzaniu. Dlatego też praktycy maja tendencję do skupiania się na wizualnych aspektach tożsamości, a pomijają inne czynni$\mathrm{ki}^{8}$. Olins definiuje tożsamość jako bezpośrednie, jawne zarządzanie (the explicit management) we wszystkich możliwych obszarach organizacji, przez co przedsiębiorstwo - poprzez doświadczenia i percepcję - jest prezentowane wszystkim swoim odbiorcom ${ }^{9}$.

Co więcej, tożsamość przedsiębiorstwa jest wyraźnym przejawem wizerunku przedsiębiorstwa, jako wynik współdziałania wszystkich odczuć, wrażeń, jakie ludzie maja na temat firmy. W tym kontekście wizerunek firmy składa się zatem z czterech wymiarów: wizerunek klasy produktów (product class image), wizerunek marki (brand image), wizerunek użytkownika marki (brand user image), wizerunek przedsiębiorstwa (corporate image) oraz wizerunek narodowości organizacyjnej (image of the nationality of corporate body ${ }^{10)}$. Jest to dość marketingowe spojrzenie na problematykę corporate identity.

U podstaw zarządzania tożsamością leży tworzenie odpowiedniego „kształtu” estetyki organizacji (lub jej marki), która wyraża „charakter” tejże organizacji (lub jej marki). Pod wpływem tych działań dochodzi do wytworzenia oczekiwanych, satysfakcjonujacych klienta przeżyć i doświadczeń, które budują stabilny system wzajemnych relacji ${ }^{11}$. Wynika to $\mathrm{z}$ faktu, że klienci nie mają dostępu do elementów składowych danej firmy czy marki, takich jak: kultura, przesłanie, strategie, wartości czy też do jej „ukrytej osobowości”. Jednak dostrzegają publiczny wizerunek danej organizacji czy jej marki, tzn. obcują z ekspresjami firmy.

Do kluczowych zagadnień zarządzania tożsamością należy zaliczyć: określenie właściwego poziomu analizy do zarządzania tożsamością, wybór i strukturyzację elementów tożsamości w taki sposób, aby wyrażały strukturę organizacji, jej oddziałów oraz rolę, jaką pełnią jej marki, wyrażanie wewnętrznej charakterystyki firmy (czym się zajmuje i co sobą reprezentuje) za pomocą różnorodnych elementów tożsamości, określenie zakresu, w jakim należy zarządzać tożsamością i wizerunkiem firmy oraz wybór właściwego stopnia spójności i różnorodności pomiędzy elementami tożsamości ${ }^{12)}$.

Jeśli tożsamość wyraża możliwość, to także sygnalizuje ograniczenia: jeśli firma wie, jaka jest, to musi również wiedzieć, jaka nie jest. Zrozumienie celów i przekonań firmy, a następnie umiejętne i dokładne zarządzanie nimi jest indywidualną sprawą każdej organizacji. Jednak im większe jest przedsiębiorstwo, tym trudniej jest zarządzać tożsamością. Wymaga to dokładniejszego kierunku. Tworzy to koncentrację i właściwy punkt widzenia, że kreowanie tożsamości jest procesem, który przebiega w czasie ${ }^{13)}$.

\section{Wnioski dla przedsiębiorstw}

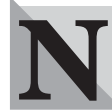
ajistotniejsze jest, by przedsiębiorstwa były spójne w prezentowaniu swej tożsamości oraz realizacji strategii. Niezgodność strategii z tożsamością podważa jej wiarygodność, zgodność potwierdza ją i utrwala ${ }^{14)}$. 
Przedsiębiorstwa, które dostrzegły korzyści wynikające $\mathrm{z}$ wykorzystania swojej tożsamości w działaniach rynkowych, stykają się z problemem wyboru odpowiedniej dla nich strategii. Z reguły firmy staja przed wyborem jednej z dwu strategii: opartej na silnym i jednoznacznym wizerunku lub zorientowanej na markę ${ }^{15)}$. Postęp technologiczny, globalizacja gospodarki przyczyniaja się do tego, że większość firm buduje swoją strategię gospodarczą zorientowaną na markę. Poprawnie zbudowane marki są wartościami uniwersalnymi, bez ograniczeń terytorialnych, prawnych oraz doskonale odpowiadaja wymogom i regułom wolnego rynku.

Jednakże wiele branż, szczególnie tych nie obracających się na rynku dóbr konsumpcyjnych, nie powinno opierać swojego wizerunku na filozofii marki. Granica znaczenia marki i preferencji na silną tożsamość firmy jest trudna do określenia. Istnieją rygorystyczne konwencje dla wielu branż, które nie podważają zasadności stosowania polityki orientowania firmy na markę. Te przedsiębiorstwa bazuja w swojej działalności na stałym wizerunku. Muszą one zgrać wszystkie elementy, które składają się na tożsamość organizacyjna, nie wymaga ona bowiem od firmy znalezienia elementów indywidualnych i charakterystycznych, lecz spójności z konwencją prezentacji branży.

Silny wizerunek firma może uzyskać wtedy, gdy przełoży strategię gospodarczą na strategię tożsamości i będzie usilnie za nią podążać.

Mimo odmiennych podejść pomiędzy teoretykami a praktykami, poglądy te można i należy łączyć. Statyczne ujęcie tożsamości, zgodnie ze szkołą teoretyczną, oraz dynamiczne podejście do zagadnienia corporate identity, zgodnie ze szkołą praktyczną, daja możliwość kompleksowego wykorzystania tego zjawiska do poprawy skuteczności organizacyjnej.

dr inz. Anna Zarębska Katedra Zarządzania Politechniki Lubelskiej

\section{PRZYPISY}

1) J. ALTKORN, Tożsamość firmy. Pojęcie, funkcje, wdrażanie, „Firma i Rynek” 1999/13, s. 67, J. ALTKORN: Zarzadzanie wizerunkiem przedsiębiorstwa $w$ czasie, „Marketing i Rynek" 2001/6.

2) A. ZARĘBSKA, Tożsamość przedsiębiorstwa - znacznie szersze spojrzenie na kulturę organizacyjna, „Przegląd Organizacji" 2003/1, s. 14.

3) Zob. np. J.M.T. BALMER, S.A. GREYSER, Managing the Multiple Identities of the Corporation, „Califormia Management Rewiev”, vol. 44, nr 3, wiosna 2002.

4) Test ten jest znany również pod nazwą DR. BALMER'S $\mathrm{AC}^{2} \mathrm{ID}$ Test ${ }^{\mathrm{TM}}$, a wcześniejsze jego wersje były publikowane w opracowaniu J.M.T. BALMER i G.B. SOENEN, The ACID Test of Corporate Identity Management ${ }^{T M}$, „Journal of Marketing Management", 15/1-3 (1999), s. 6992 [w:] J.M.T. BALMER, S.A. GREYSER, op.cit., wiosna 2002

5) Szerzej na ten temat zob. A. ZARĘBSKA, op.cit., 2003/1 oraz A. ZARĘBSKA, Rozważania nad misja w kontekście tożsamości wspótczesnych przedsiębiorstw, „Ekonomika i Organizacja Przedsiebiorstwa" 2005 (w druku).

6) T.C. MELEWAR, E. JENKINS, Defining the Corporate Identity Construct, „Corporate Reputation Review”, vol. 5 , nr 1, 2002, s. 81.

7) T.C. MELEWAR, E. JENKINS, op.cit., 2002, s. 80.

8) J. BALMER, G. SOENEN, A New Approach to Corporate Identity Magement, International Centre for Corporate Identity Studies, „Working Paper” 1998/5, [w:] T.C. MELEWAR, E. JENKINS, Defining the Corporate Identity Construct, „Corporate Reputation Review” vol. 5, nr, 1, 2002, s. 77, J. BALMER Corporate Identity and the Advent of Corporate Marketing, ,Journal of Marketing Management" 1998, 14, s. 963-996.

9) W. OLINS, The New Guide to Identity, Gower, Hampshire 1995, s. 3.

10) T.C. MELEWAR, E. JENKINS, op.cit., 2002, s. 77.

11) B. SCHMITT, A. SIMONSON, Estetyka $w$ marketingu. Strategiczne zarzadzanie markami, tożsamościa $i$ wizerunkiem firmy, Wydawnictwo Profesjonalnej Szkoły Biznesu, Kraków 1999, s. 75.

12) B. SCHMITT, A. SIMONSON, op.cit., s. 95.

13) M. ROWDEN, The Art of Identity. Creating and Managing a Succesful Corporate Identity, Gower, Hampshire 2000, s. $2-3$.

14) J. ALTKORN, op.cit., 1999/13, s. 69.

15) J. FILIPEK, Strategie tożsamości firm, „Firma i Rynek” 1999/13, s. 75 . 